
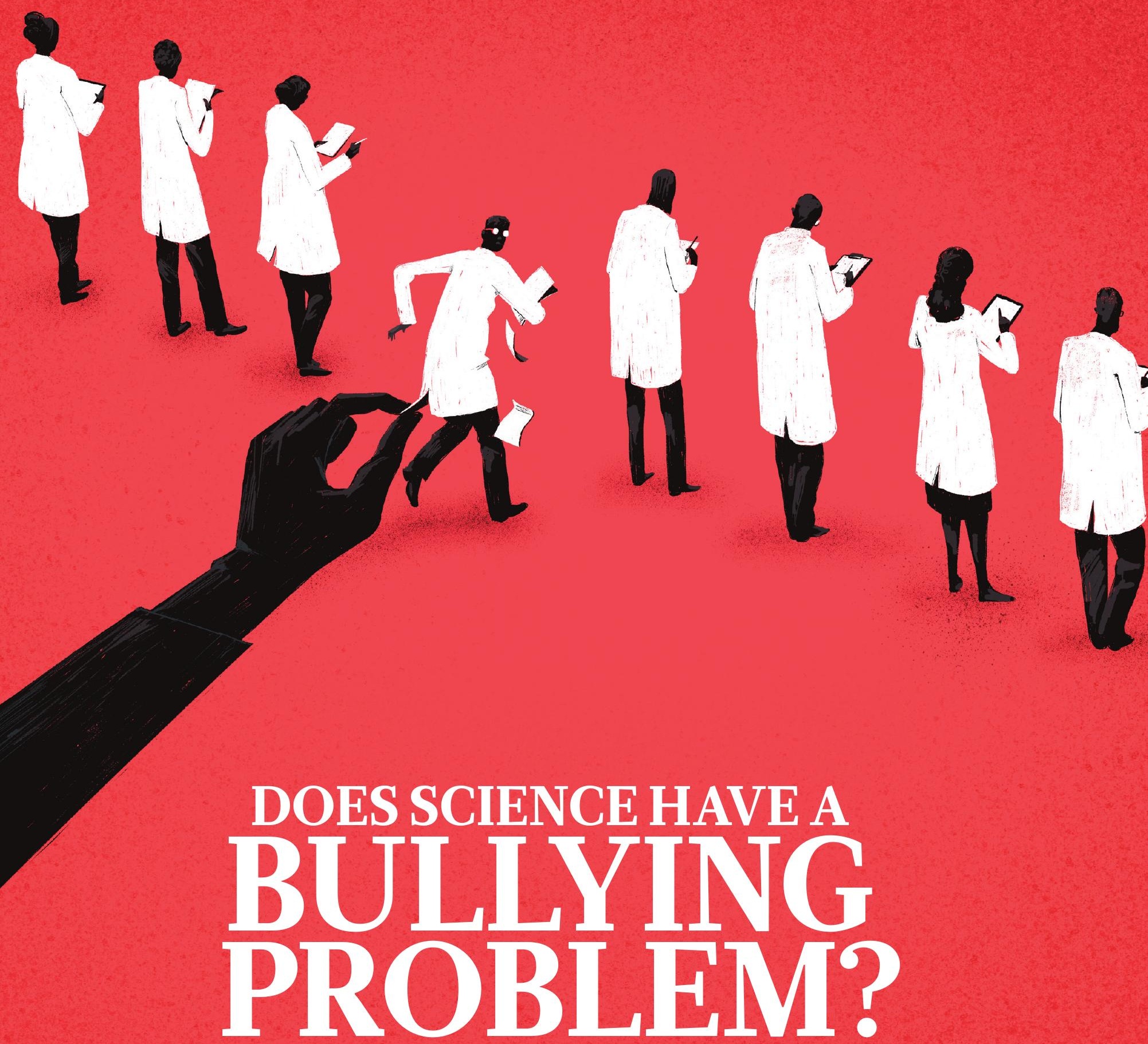

A spate of bullying allegations have rocked some highprofile science institutions. Here's how researchers, universities and funders are dealing with the issue.

BY HOLLY ELSE 


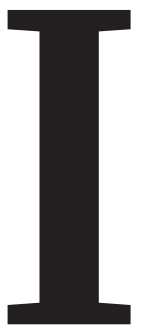

n August, accusations of bullying roiled the Institute of Cancer Research in London, one of the leading science centres in the United Kingdom. A prominent cancer researcher there, geneticist Nazneen Rahman, resigned from the institute following an investigation into allegations that she had bullied her staff. And in an unprecedented move, the biomedical charity the Wellcome Trust revoked $£ 3.5$ million (US $\$ 4.5$ million) of the funding it had given her.

Three months on, many more people from Rahman's lab have left the institute. Yet most of the details about the case remain hidden from the public: Rahman has not commented about the allegations and the institute has released little information. It even withheld certain findings from the Wellcome Trust because they contained highly confidential personal information. The secrecy - and the resulting confusion - are prime examples of the difficulties that scientific institutions and researchers face in dealing with the thorny issue of bullying.

The case is part of a spate of allegations that have rocked major scientific institutions in the past year. At Germany's prestigious Max Planck Society, two directors were accused of bullying; and the UK-based Leverhulme Trust revoked $£ 1$ million in funding from palaeontologist Nicholas Longrich at the University of Bath following an investigation into bullying allegations. One of the world's leading genomics centres, the Wellcome Sanger Institute in Hinxton, UK, has also investigated claims of bullying. But the decision to clear the Sanger's management of this and other allegations has led some of those who complained to question the scope and extent of the probe. The Wellcome and other science funders, including Cancer Research UK (CRUK), have announced policies this year that prohibit bullying as well as other forms of harassment.

The flurry of activity surrounding bullying has raised questions about how scientific organizations are run and how some researchers conduct themselves. Here, Nature examines what constitutes bullying, why so many accusations are arising and what impact it is having on research and on those who do it.

\section{What is bullying?}

Bullying between colleagues is commonly defined by psychologists, unions and workplace scholars as repeated and malicious mistreatment of someone that results in harm.

At its most obvious, this behaviour involves shouting, insulting or intimidating victims. But bullying can include more subtle actions, says Alison Antes, a workplace psychologist who studies researcher leadership and management practices at Washington University in St Louis, Missouri.

It can take the form of someone spreading malicious rumours about another, undermining their work and opinions, or withholding information necessary for them to do their jobs. Supervisors can become bullies if they are overbearing, constantly changing a person's duties or giving them impossible workloads or unachievable deadlines. These more subtle forms of malicious conduct can often cause the most problems because they tend to be difficult to detect and are open to differing interpretations, says Antes.

Some actions might fit into a grey zone. What one person considers firm management, another might consider bullying, says Antes. It is not difficult to imagine, for example, a $\mathrm{PhD}$ supervisor giving a student a raft of unfamiliar experiments to complete, with a deadline that leaves the student stressed and working all night. Is this bullying?

The answer depends on the broader behaviour and approach, explains Loraleigh
Around $40 \%$ say that they have witnessed or heard about bullying happening to someone else. This is considerably higher than the reports of bullying in the general workplace. Studies in the United States report that $10-14 \%$ of people in the general working population say that they have experienced bullying over the previous year ${ }^{1}$.

One of the largest studies of bullying in universities - surveying 14,000 highereducation staff - was published by the UK University and College Union in 2012 (ref. 2). It found that the rate of bullying varied hugely among the 92 institutions surveyed. Between $2 \%$ and $19 \%$ of staff at each university said they were always or often subject to bullying at work.

Universities came out better than average in an earlier survey, this one published in 2000 and sponsored by the British Occupational Health Research Foundation ${ }^{3}$, which included

\section{“THIS ISN'T PECULIAR TO SCIENCE, WE WILL SEE IT IN ALL WALKS OF LIFE."}

Keashly, a communications scientist at Wayne State University in Detroit, Michigan. 'Tough' supervisors are not bullies if they set up clear expectations and communicate them directly to reportees. They will also acknowledge and appreciate staff members who meet those expectations. If employees do not achieve their goals, good supervisors will give specific and constructive feedback, she says.

Naomi Ellemers, a social psychologist at Utrecht University in the Netherlands who has studied how people are treated in academia, adds that supervisors on the right side of the line will give people the time, support and resources to achieve their goals, and treat them respectfully.

A bully, by contrast, is typically not interested in developing relationships that allow their subordinates to grow professionally, says Keashly. They might also dish out bullying behaviour on a whim, whether or not the person they are targeting has failed to perform well, she adds.

\section{How common is it in research - and is it getting worse?}

Nobody knows how much bullying goes on in science, because few people have investigated the issue. Studies of bullying in workplaces began only in the 1990s, and some researchers have yet to examine what goes on in their own back yards.

But Keashley thinks that this needs to change so that the behaviour can be better managed.

Her research, which draws on published evidence of bullying in academia from around the world, suggests that, in general, one-quarter to one-third of academics say that they have been bullied in the past year ${ }^{1}$.
5,288 workers in 15 fields. Just $7 \%$ of the 483 respondents who work in higher education say that they are occasionally or regularly bullied - the third-lowest score of all the professions looked at. (Only retailing and manufacturing has less bullying.) But Cary Cooper, a workplace psychologist at the University of Manchester, UK, who co-authored the study, says that this under-represents the true problem in universities. His survey had a relatively strict definition of bullying: workers qualified as being bullied if they had experienced persistent demeaning and devaluing treatment.

For comparison, a study of bullying in neonatal intensive-care units at 17 Greek hospitals found that more than half of the almost 400 doctors and nurses surveyed had experienced bullying ${ }^{4}$.

And an online survey of more than 1,000 US adults conducted last April reported that $19 \%$ had experienced bullying at work ${ }^{5}$.

Because there are so few data about bullying in research, and specifically science, Keashley and other researchers say it is not clear whether the problem is getting worse. Matt Waddup, head of policy at the UK University and College Union in London, says that bullying is not always easy to pin down in cases that come to the union, because it is often a component of other problems that members have. But he thinks it is on the rise.

Part of the reason could be that people across society are reconsidering what types of behaviours are acceptable. Ellemers says that the \#metoo movement has made it a little easier for those in low-power positions to report bullying, harassment and other inappropriate behaviours exerted by those above them. It has also spurred those in charge to take action instead of dismissing or ignoring the 
complaints, which often happened previously, she says.

Karen Vousden, chief scientist at CRUK in London, which recently introduced an antibullying policy for the labs it funds, says that society at large is now discussing these issues. "This isn't peculiar to science, we will see it in all walks of life," she says.

\section{What contributes to bullying in science?}

For the most part, says Antes, principal investigators generally "love what they do and do the right thing". But there are clearly exceptions - and certain factors in scientific research seem to encourage what some academics call abusive supervision.

Lab heads wield a lot of power over their trainees - students and postdocs - who depend on them for help, recommendations and opportunities, says Ellemers. This type of dependence and hierarchical structure can allow people to get away with bullying because it makes it difficult for those targeted or watching to confront the perpetrator, raise it with more senior colleagues or simply walk out. As a result, bullying can continue unchallenged for a long time, she says.

And bullying is not always malicious: the intense pressure to get grants, results and publications can push people to behave in problematic ways unintentionally, adds Antes.

According to another idea, science is susceptible to bullying partly because of the types of people who tend to choose that career. "In academia you do deal with a lot of individuals who are very intelligent but also have large egos," says Matthew Martin, who

\section{“ONE OF THE WORST THINGS YOU CANDO IS START THE PROCESS AND ABANDON IT.”}

studies bullying at West Virginia University, in Morgantown. And some egocentric people might be more prone to bullying because they are unconcerned with others' feelings, he proposes.

Often in science, there can be only a handful of people who are experts in a specific field, so junior researchers who experience bullying might think that it is worth putting up with the behaviour because in the long run it will pay off for them, explains Antes. "Your career success starts to be woven around their success," she says, making it even harder to speak out about poor behaviour.

And some researchers could have spent their early careers in a lab where bullying behaviour was the norm. They might be trying to use these tactics on their staff because they think that is what made them successful. So the bullying behaviours are actually coming from a place of care, says Antes - a perception that this will help others.

\section{What are scientific institutions doing about it?}

The majority of UK universities have policies that prohibit bullying and harassment, says Waddup. These documents typically include definitions and examples and they advise on what to do if someone encounters such problems.

In July, the University of Bath reprimanded Longrich after it found that he had violated its dignity and respect policy. The institution issued him with a verbal warning and made changes to his 'supervisory arrangements'. Some people who have worked with Longrich feel that the university's initial actions did not go far enough. Subsequently, the Leverhulme Trust, which had funded Longrich, revoked his $£ 1$-million grant. Longrich has not responded to Nature's repeated requests for comment. A University of Bath spokesperson told Nature: "Our HR procedures ensure people involved are treated reasonably, consistently and fairly."

In general, having policies is not enough, says C. K. Gunsalus, a specialist in research integrity at the University of Illinois at UrbanaChampaign. To stamp out bad behaviour, leaders need to apply policies consistently and show that bullying has consequences, she says. "One of the worst things you can do is start the process and abandon it. It reinforces the problem."

Bullying policies vary widely around the world. They are less common at universities and other institutions in the United States than in the United Kingdom. Unpublished research by Leah Hollis at Morgan State University in Baltimore, Maryland, who studies bullying in higher education, suggests that only around

most people do," she says.

Those who are bullied are more likely to be distracted and make mistakes, says Keashly. At worst, bullying can contribute to long-term problems with mental or physical health. That has an impact beyond the victim themselves, eroding the creativity, productivity and well-being of an entire lab.

After Rahman resigned and the Wellcome revoked her funding, the upheaval had ripple effects. The Institute of Cancer Research says that it followed standard processes for when a team leader leaves. Only one-third of the 15 people in her research team still work at the institute.

One concern about bullying is that it can drive people away from science permanently, especially those who were the targets, says Vousden. "Our workforce is incredibly precious. We spend huge amounts of time on mentoring and funding people," she says. "Our scientists are in some degree our most valuable component."

\section{What needs to be done?}

The next big job for institutions, says Vousden, is to create an open and supportive atmosphere in which people feel comfortable enough to bring up any concerns in a non-confrontational way. This can help to prevent situations from escalating "to the point where you have 50 people making complaints about 10 years of behaviour", she says.

Towards this goal, CRUK will be auditing the institutions it funds to check that they are adhering to its anti-bullying policy.

Another important step is for universities to offer training to scientists who assume management roles, says Cooper. Institutions should also reward researchers for taking on management tasks.

Hollis says that institutions without bullying policies should develop and put them in place. Crucially, they then need to follow the procedures. "It sounds simple, but many schools don't follow such policies," she says.

And the policies must apply "regardless of whether the bully is a vice-president or grounds workers", says Hollis. "Bullying occurs because the organization allows it to occur."

As harassment and bullying accusati have captured more attention in the past year, several major science funders have stepped up to develop policies. The Wellcome Trust's policy specifically prohibits bullying as well as harassment. Some other funders are less clear. Neither the US National Science Foundation nor the US National Institutes of Health specifically mentions bullying in its anti-harassment policies.

\section{What is the effect on science and scientists?}

No one knows whether bullying has a negative impact on science - but Antes suspects it does. "Maybe some people can thrive in that environment, but I don't think
Holly Else is a reporter with Nature in London.

1. Keashley, L. SPECTRA 51, 23-28 (2015).

2. University and College Union. 2012 Occupational Stress Survey: the Relationships stressor in HE (UCU, 2012); available at https://go.nature. $\mathrm{com} / 2 \mathrm{~s} 32 \mathrm{qdt}$

3. Hoel, H. \& Cooper, C. Destructive conflict and bullying at work (Manchester School of Management, 2000); available at https://go.nature. com/2zhd9kl

4. Chatziioannidis, I., Bascialla, F. G., Chatzivalsama, P., Vouzas, F. \& Mitsiakos, G. BMJ Open 8, e018766 (2018).

5. Namie, G. 2017 Workplace Bullying Institute U.S Workplace Bullying Survey (Workplace Bullying Institute, 2017); see https://go.nature.com/2kqjlsu 


\section{CLARIFICATION}

Some phrasing in the News Feature 'Does science have a bullying problem?' (Nature 563, 616-618; 2018) did not make it clear that Nazneen Rahman resigned from the Institute of Cancer Research before the Wellcome Trust revoked her funding. 